\title{
Seksuele disfunctie en relatieproblemen na prostaatkankerbehandeling: De gewenste zorg vanuit het oogpunt van patiënt en partner
}

\author{
Lorena A. Grondhuis Palacios ${ }^{1}$ Esmée M. Krouwel ${ }^{1} \cdot$ Brenda L. den Oudsten $^{2} \cdot$ Marjolein E. M. den $^{2}$ \\ Ouden $^{3} \cdot$ Gert Jan Kloens $^{4} \cdot$ Grethe van Duijn $^{2} \cdot$ Hein Putter $^{5} \cdot$ Rob C. M. Pelger $^{1} \cdot$ Henk W. Elzevier ${ }^{1}$
}

Published online: 16 May 2017

(C) The Author(s) 2017. This article is an open access publication.

Samenvatting Erectiele disfunctie (ED) is een van de meest voorkomende gevolgen van prostaatkankerbehandeling en kan leiden tot verandering in een partnerrelatie. Doel van deze studie was het inventariseren van seksuologische en/of relationele problemen en onderzoeken welke vorm van aanvullende zorg gewenst wordt door patiënt en partner. Dit vond plaats middels een vragenlijstonderzoek onder mannen gediagnosticeerd met prostaatkanker onder active surveillance of behandeld met laparoscopische radicale prostatectomie, brachytherapie, intensiteitsgemoduleerde radiotherapie of hormonale therapie. Indien mogelijk werden partners geïncludeerd. Van 250 patiënten had $80,5 \%$ last van matig tot ernstige erectieklachten. De helft $(53,7 \%)$ werd behandeld voor ED, waarbij een derde $(30,7 \%)$ deels tevreden was en een kwart $(25,7 \%)$ ontevreden. Van 168 partners had 50,6\% moeite met de veranderingen rond seksualiteit. De meerderheid van de mannen $(74,7 \%)$ zou het wenselijk vinden om drie maanden na behandeling tijdens een standaardconsult seksualiteit te bespreken met een uroloog-seksuoloog.

Lorena A. Grondhuis Palacios

1.a.grondhuis_palacios@lumc.nl

1 afdeling Urologie, Leids Universitair Medisch Centrum, Leiden, Nederland

2 afdeling Medische en Klinische Psychologie, Universiteit van Tilburg, Tilburg, Nederland

3 Lectoraat Verpleegkunde, Saxion Universiteit van Toegepaste Wetenschappen, Enschede, Nederland

4 afdeling Psychologie, Educatie en Pedagogische Wetenschappen, Erasmus Universiteit Rotterdam, Rotterdam, Nederland

5 afdeling Medische Statistiek, Leids Universitair Medisch Centrum, Leiden, Nederland
Trefwoorden seksuele disfunctie - erectiele disfunctie . prostaatkanker · partners · seksuele gezondheidszorg · seksuele counseling

\section{Suitable sexual health care after prostate cancer treatment: A cross-sectional survey among Dutch men and their partners}

\begin{abstract}
Erectile dysfunction (ED) is one of the most common side effects of prostate cancer (PC) treatment and may lead to changes in a relationship. The aim of this study was to identify sexual and/or relational problems and to investigate what kind of supportive care is preferred by patients and their partners. A cross-sectional survey was performed among men diagnosed with PC enrolled in active surveillance or treated with laparoscopic radical prostatectomy, brachytherapy, intensity-modulated radiotherapy or hormonal therapy. If possible, partners were included as well. Out of 250 patients, $80,5 \%$ suffered from moderate to severe erectile complaints. Half of them $(53,7 \%)$ was treated for ED and a great part was partially $(30,7 \%)$ up to not satisfied $(25,7 \%)$. Out of 168 partners, $50,6 \%$ found it difficult to cope with changes around sexuality. The majority of men $(74,7 \%)$ preferred a standard consultation with a urologist-sexologist three months after treatment to discuss sexuality.
\end{abstract}

Keywords sexual dysfunction - erectile dysfunction . prostate cancer $\cdot$ partners $\cdot$ sexual health care $\cdot$ sexual counseling 


\section{Introductie}

Prostaatkanker is een van de meest voorkomende vormen van kanker bij mannen, met elk jaar gemiddeld 11.000 nieuwe gevallen [1]. Toegenomen publieke bewustwording en ingebruikname van de prostaatspecifiek antigeen (PSA) test hebben daarnaast gezorgd voor een steeds vroegere detectie van prostaatkanker [2]. De behandelmethode is afhankelijk van verschillende prognostische factoren en daarnaast, indien mogelijk, de voorkeur van de patiënt. Vroege detectie en effectievere behandelmethoden hebben geleid tot een toename in ziektevrije en algemene overleving. Desondanks kan een prostaatkankerbehandeling van grote invloed zijn op de kwaliteit van leven [3]. Seksuele disfunctie (SD) is, naast urine-incontinentie, een van de meest voorkomende aan de behandeling gerelateerde bijwerkingen, met erectiele disfunctie (ED) als voornaamste klacht [4]. Vijf jaar na de diagnose ondervindt 79,3\% van de patiënten ED als gevolg van een radicale prostatectomie (RP) en $63,5 \%$ als gevolg van externe radiotherapie (RT) [5]. Bij $72 \%$ van de mannen vindt significant verlies van kwaliteit van leven plaats als gevolg van ED [6]. De huidige ED-behandeling bestaat uit PDE-5-remmers, intra-urethrale alprostadil, vacuümtherapie, intracaverneuze injecties en penisprotheses [7]. Helaas zijn deze behandelingen niet in alle gevallen toereikend. Behandeling met alprostadil of tadalafil ten opzichte van placebo laat geen significante verbetering zien in RP-gerelateerde ED $[8,9]$.

Verandering op het gebied van seksualiteit heeft niet alleen invloed op de patiënt, maar ook op zijn partner. Prostaatkanker leidt tot hogere stressniveaus bij de partner van de patiënt; $38 \%$ van de partners is ontevreden over de veranderde seksualiteit $[10,11]$. Zowel patiënten als partners lijden onder de gevolgen van de behandeling, wat de relatie negatief kan beïnvloeden [12, 13]. Desalniettemin is nog weinig onderzoek gedaan naar welke seksuele gezondheidszorg adequaat zou zijn bij SD ten gevolge van prostaatkankerbehandeling [14]. Tijdens follow-up zijn de mogelijkheden om de impact van de behandeling te bespreken beperkt, omdat prioriteit wordt gegeven aan behandeling van de ziekte zelf [15]. Dit kan het psychologisch welzijn van zowel patiënt als partner verslechteren en leiden tot afname van de kwaliteit van leven [16].

Doel van het onderzoek was om de seksuele gezondheidszorg na een behandeling voor prostaatkanker en de tevredenheid over ED-behandelingen te evalueren. Tevens was het doel te onderzoeken welke hulpverlener, welke vorm van seksuele counseling en op welk moment als wenselijk wordt ervaren vanuit het perspectief van patiënten en hun partners.

\section{Methode}

Deze cross-sectionele studie is uitgevoerd onder patiënten die in het Leids Universitair Medisch Centrum (LUMC) in de periode $2013 \mathrm{t} / \mathrm{m} 2015$ gediagnosticeerd zijn met prostaatkanker en in active surveillance (AS) protocol gingen of een laparoscopische radicale prostatectomie (LRP), brachytherapie (BT), intensiteitsgemoduleerde radiotherapie (IMRT) of hormonale therapie (HT) behandeling hebben ondergaan. Tevens werden mannen geïncludeerd die in de periode $2013 \mathrm{t} / \mathrm{m} 2015$ aanvingen met een van bovengenoemde behandelingen na een eerdere periode van AS. Patiëntgegevens, zoals leeftijd, TNM-stadiëring en type behandeling(en) zijn verkregen uit de oncologieregistratie. Bij de gemeentelijke basisadministratie werd gecontroleerd welke patiënten naar het buitenland waren geëmigreerd; deze patiënten werden geëxcludeerd. Ook werd op deze manier nagegaan welke patiënten inmiddels waren overleden om te vermijden dat hun nabestaanden niet abusievelijk werden aangeschreven. In totaal werden 590 mannen aangeschreven.

Patiënten die waren behandeld met IMRT in combinatie met HT gedurende 6 en 24 maanden, werden voor de overzichtelijkheid samengevoegd.

De vragenlijsten zijn samengesteld door de auteurs en gebaseerd op het doel van deze studie en op literatuuronderzoek. In februari 2015 werd een pilot uitgevoerd onder vijf leden van de Prostaatkankerstichting om de inhoud en doelmatigheid van de vragenlijsten te evalueren. Aan de hand daarvan werden inhoud, formulering van de vragen en antwoordmogelijkheden aangepast. Zo is besloten om het begrip 'intimiteit' te hanteren, waarbij gedoeld wordt op de vaardigheid om gevoel van saamhorigheid en verbintenis te delen met een partner in een verbale, non-verbale vorm, via gedrag en door seksuele en niet-seksuele affectieve aanraking.

In juni 2015 werden informatiebrieven en ingesloten toestemmingsformulieren met gefrankeerde retourenveloppen per post apart verzonden naar patiënten en partners. Bij een positieve reactie werden de vragenlijsten aan patiënt en diens partner in aparte enveloppen verstuurd om ieders privacy te waarborgen. De reden om niet deel te willen nemen, kon worden aangegeven op het toestemmingsformulier.

De patiëntenvragenlijst bestond uit 47 items over sociodemografische kenmerken, seksualiteit rond de behandeling en seksuele gezondheidszorg. De partnervragenlijst bestond uit 14 items over sociodemografische kenmerken, seksualiteit rond de behandeling en inventarisatie van de behoefte aan seksuele counseling.

Door de opbouw van de vragenlijst werd de vraag met betrekking tot welk moment als meest geschikt werd bevonden voor seksuele counseling per abuis door een aantal deelnemers overgeslagen. Antwoorden van deelnemers die 
de vraag wel hadden beantwoord, zijn in de resultaten beschreven.

\section{Statistische analyse}

Data-analyse werd verricht middels SPSS versie 23 (Chicago, VS). Demografische en klinische variabelen werden beoordeeld met beschrijvende statistiek. Numerieke waarden werden beschreven met gemiddelde (SD) en categorische variabelen met aantallen (\%). Verschillen in categorische klinische uitkomsten werden geanalyseerd met de McNemar-toets. Tweezijdige $p$-waarden $<0,05$ werden als statistisch significant beschouwd.

\section{Ethiek}

Het protocol voor deze studie werd in juni 2015 goedgekeurd door de Medisch Ethische Commissie van het LUMC. Goedkeuring was essentieel, aangezien het een vragenlijst betrof met delicate vragen en privacy van de deelnemers gewaarborgd diende te worden.

\section{Resultaten}

In totaal kwamen 584 mannen in aanmerking voor deelname aan deze studie (zes patiënten vielen af in de loop van de studie wegens overlijden). Er werden 449 toestemmingsformulieren geretourneerd; 282 mannen waren initieel bereid te participeren. Van 253 mannen werd een ingevulde vragenlijst ontvangen, resulterend in een respons van $43,3 \%$. Onder de mannen die niet wensten deel te nemen $(n=168)$, waren de meest genoemde redenen geen interesse $(n=49)$, verbetering op dit gebied is onbelangrijk $(n=33)$ en vragen zijn te persoonlijk $(n=29)$.

\section{Sociodemografische kenmerken}

De gemiddelde leeftijd van de mannen was 69,3 jaar (SD 6,9; range 45-89), de meerderheid $(78,6 \% ; n=198)$ was gepensioneerd. Bijna $78 \%(n=196)$ was getrouwd, met een gemiddelde relatieduur van 40,3 jaar $(S D=14,1$; range 2-64). De diagnose prostaatkanker werd gesteld op een gemiddelde leeftijd van 66,2 jaar $(\mathrm{SD}=6,7$; range $=$ $42-86)$ en $92,4 \%(n=232)$ had gelokaliseerd prostaatcarcinoom ten tijde van de diagnose. IMRT in combinatie met HT was de meest voorkomende behandeling $(26,9 \%$; $n=68)$, gevolgd door LRP $(25,3 \% ; n=64)$ en IMRT $(23,3 \% ; n=59)$. In tab. 1 staat aanvullende informatie over de demografische en de klinische kenmerken van de deelnemers.
Tabel 1 Demografische kenmerken.

\begin{tabular}{|c|c|}
\hline & $n(\%)$ \\
\hline \multicolumn{2}{|l|}{$\overline{\text { leeftijd (jaren) }}$} \\
\hline gem. $69,3(\mathrm{SD}=6,9 ;$ range $=45-89)$ & $253(100)$ \\
\hline \multicolumn{2}{|l|}{ werkzaamheid } \\
\hline werkzaam & $47(18,6)$ \\
\hline niet werkzaam & $7(2,8)$ \\
\hline gepensioneerd, werkzaam & $69(27,4)$ \\
\hline gepensioneerd, niet werkzaam & $129(51,2)$ \\
\hline \multicolumn{2}{|l|}{ opleiding } \\
\hline geen/lager onderwijs of basisschool & $16(6,4)$ \\
\hline vmbo/mavo/lbo & $65(25,9)$ \\
\hline mbo & $56(22,3)$ \\
\hline havo/vwo & $33(13,1)$ \\
\hline hbo/wo & $81(32,3)$ \\
\hline \multicolumn{2}{|l|}{ burgerlijke staat } \\
\hline ongehuwd & $19(7,5)$ \\
\hline gehuwd & $196(77,8)$ \\
\hline samenwonend & $11(4,4)$ \\
\hline weduwnaar & $14(5,6)$ \\
\hline anders & $12(4,8)$ \\
\hline \multicolumn{2}{|l|}{ duur relatie (jaren) } \\
\hline gem. $40,3(\mathrm{SD}=14,1 ;$ range $=2-64)$ & $217(85,8)$ \\
\hline \multicolumn{2}{|l|}{ leeftijd van diagnose (jaren) } \\
\hline gem. $66,2(\mathrm{SD}=6,7 ;$ range $=42-86)$ & $252(98,8)$ \\
\hline \multicolumn{2}{|l|}{ TNM-stadiëring [17] } \\
\hline $\mathrm{T}$ - primaire tumor & $232(92,4)$ \\
\hline $\mathrm{N}$ - regionale lymfeklieren & $11(4,4)$ \\
\hline M - metastasen op afstand & $8(3,2)$ \\
\hline \multicolumn{2}{|l|}{ beleid ten aanzien van de diagnose } \\
\hline active surveillance (AS) & $17(6,7)$ \\
\hline laparoscopische radicale prostatectomie (LRP) ${ }^{\mathrm{a}}$ & $64(25,3)$ \\
\hline brachytherapie (BT) & $25(9,9)$ \\
\hline intensiteitsgemoduleerde radiotherapie (IMRT) & $59(23,3)$ \\
\hline IMRT gecombineerd met $\mathrm{HT}^{\mathrm{b}}$ & $68(26,9)$ \\
\hline hormonale therapie (HT) & $16(6,3)$ \\
\hline anders $^{\mathrm{c}}$ & $1(0,4)$ \\
\hline
\end{tabular}

${ }^{\text {aInclusief LRP gecombineerd met IMRT }(n=5) \text { en LRP gecombineerd }}$ met $\operatorname{HT}(n=1)$

${ }^{\mathrm{b}}$ Inclusief BT gecombineerd met HT $(n=8)$ en IMRT gecombineerd met LRP en HT $(n=4)$

${ }^{\mathrm{c}}$ Pelviene lymfeklierdissectie

\section{Seksualiteit na behandeling}

Voor de behandeling had $34,6 \%$ van 250 deelnemende mannen last van matig tot ernstige erectieklachten. $\mathrm{Na}$ de behandeling steeg dit antal significant: $80,5 \%$ rapporteerde matig tot ernstige $\mathrm{ED}(p<0,001 ; \mathrm{McNemar}$-toets). De helft van de patiënten $(50,0 \% ; n=124)$ was niet meer seksueel actief na de behandeling en 78,2\% $(n=190)$ gaf verslechtering van seksualiteit aan. Tab. 2 geeft ED weer voor en na beleid ten aanzien van diagnose, met het grootste 
Tabel 2 Matig tot ernstige ED voor en na beleid ten aanzien van diagnose.

ED voor beleid $n$

$(\%)$

beleid ten aanzien van de diagnose

\begin{tabular}{lllll}
\hline active surveillance (AS) & $5(29,4)$ & $6(35,3)$ & 5,9 & n. s. \\
laparoscopische radicale prostatectomie $^{\mathrm{a}}$ (LRP) & $20(31,3)$ & $60(93,8)$ & 62,5 & $<0,001$ \\
brachytherapie (BT) $_{\text {intensiteitsgemoduleerde radiotherapie (IMRT) }}$ & $14(56,0)$ & $22(88,0)$ & 32,0 & $<0,05$ \\
IMRT gecombineerd met HT & $25(42,4)$ & $46(78,0)$ & 35,6 & $<0,001$ \\
hormonale therapie (HT) $^{\mathrm{b}}$ & $17(25,0)$ & $50(73,5)$ & 48,5 & $<0,001$ \\
anders $^{\mathrm{c}}$ & $5(31,3)$ & $12(75,0)$ & 43,7 & $-<0,05$ \\
\hline
\end{tabular}

n. s. niet significant

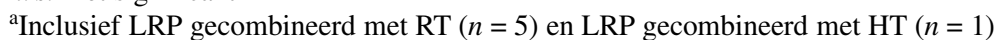

${ }^{\mathrm{b}}$ Inclusief HT gecombineerd met brachytherapie $(n=8)$ en HT gecombineerd met RT en LRP $(n=4)$

cPelviene lymfeklierdissectie $(n=1)$, deelnemer heeft de behorende vragen niet beantwoord

${ }^{\mathrm{d}}$ McNemar-toets

verschil in percentiele punten na LRP en IMRT in combinatie met HT met $62,5 \%$ en $48,5 \%$ respectievelijk (tab. 2).

\section{ED-behandelingen}

Bij mannen met ED werden PDE-5-remmers het meeste ter sprake gebracht $(50,0 \% ; n=94)$, gevolgd door een eenmalig consult om seksualiteit te bespreken $(12,8 \% ; n=24)$, intra-urethrale medicatie $(11,2 \% ; n=21)$, intracaverneuze injecties $(6,9 \% ; n=13)$ en vacuümtherapie $(5,4 \% ; n=$ 10). De helft van de mannen met ED $(50,2 \% ; n=101)$ maakte gebruik van het aanbod. Een derde $(34 \% ; n=64)$ gaf aan hier geen behoefte aan te hebben. Eén op de zeven $(14,4 \% ; n=27)$ gaf aan dat dergelijke hulpmiddelen nooit zijn aangeboden. Van de 101 mannen die werden behandeld voor ED was een derde deels tevreden $(30,7 \%)$ en een kwart ontevreden $(25,7 \%)$. In deze groep waren de mannen die met BT $(68,8 \% ; n=11)$ en IMRT $(56,3 \% ; n=$ 9) waren behandeld het meest tevreden. Het minst tevreden waren mannen die operatieve of hormonale behandeling hadden ondergaan; slechts $31,9 \%$ van de 47 mannen die waren behandeld met LRP was tevreden en van de drie mannen die na hormonale therapie ED-behandeling had geprobeerd, was slechts één man tevreden. Onder de mannen die zowel bestraling als hormonale behandeling hadden gekregen, was de helft $(47,1 \% ; n=8)$ tevreden, een derde ontevreden $(35,3 \% ; n=6)$ en $17,6 \%$ van de 17 mannen was deels tevreden. Redenen voor ontevredenheid waren beperkte resultaten $(54,8 \% ; n=17)$, pijn $(6,5 \% ; n=2)$ en hoge kosten $(3,2 \% ; n=1)$. Zes patiënten $(19,4 \%)$ gaven aan het middel nog niet geprobeerd te hebben. Aan minder dan een derde $(31,2 \% ; n=58)$ werd de mogelijkheid geboden met een gespecialiseerde zorgverlener te spreken, zoals een (uroloog-)seksuoloog.

\section{Partners}

Aan de studie hebben 174 partners deelgenomen (171 vrouwen, 3 mannen). De gemiddelde leeftijd was 65,5 jaar $(\mathrm{SD}=7,6 ;$ range $=45-86)$, de meerderheid $(65,6 \% ; n=$ 114) was gepensioneerd.

Ongeveer de helft van de partners $(50,6 \% ; n=81)$ rapporteerde moeite te hebben met de veranderde situatie omtrent seksualiteit en $51 \%(n=85)$ ervaarde matig tot ernstige problemen. Van urine-incontinentie, een andere aan de behandeling gerelateerde bijwerking, ondervond $61,6 \%$ $(n=101)$ geen problemen. Een groot deel $(69,3 \% ; n=$ 115) van de partners gaf aan dat veranderingen in intimiteit geen invloed hadden gehad op de relatie en de meerderheid $(86,9 \% ; n=93)$ vermeldde geen behoefte te hebben aan hulpverlening omtrent seksualiteit en relatie. Een enkeling $(11,5 \% ; n=6)$ vermeldde als reden hiervoor dat een langdurige relatie in staat was dergelijke problemen te overwinnen en ondanks het feit dat een seksuele relatie niet meer van toepassing was, andere vormen van intimiteit tevens als bevredigend werden ervaren. Een aantal partners $(25 \% ; n=13)$ gaf aan de nieuwe situatie geaccepteerd te hebben en ervaarde zelfs dat de communicatie binnen de relatie was verbeterd.

Bijna een derde $(29,8 \% ; n=36)$ rapporteerde echter wel problematiek omtrent de veranderde seksualiteit en de relatie, waarbij gebrek aan intimiteit $(33,3 \% ; n=12)$, verlies van een seksuele relatie $(27,8 \% ; n=10)$, omgaan met de frustraties van hun partner, die werden veroorzaakt door zowel niet overweg kunnen gaan met ED als met het gevoel van verlies van mannelijkheid $(25 \% ; n=9)$ en toegenomen spanning in de relatie $(13,9 \% ; n=5)$ het meest werden genoemd. 


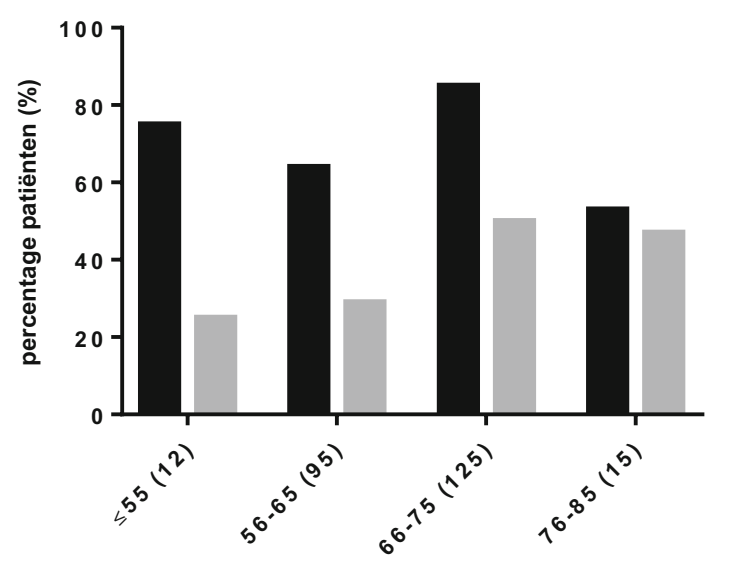

leeftijd waarop de diagnose werd gesteld in jaren ( $n$ )

consult met een uroloog-seksuoloog

consult met een (oncologie) verpleegkundige

Figuur 1 Behoefte aan consult met een uroloog-seksuoloog en (oncologie)verpleegkundige.

\section{Gewenste seksuele gezondheidszorg}

De meerderheid van de mannen $(74,7 \% ; n=183)$ gaf aan behoefte te hebben aan een standaard gepland consult met een uroloog-seksuoloog om seksuele gezondheidsproblemen na prostaatkankerbehandeling te bespreken. Ongeveer een kwart $(22,4 \% ; n=55)$ verklaarde dat een dergelijke afspraak enkel nuttig is indien de patiënt aangeeft hier behoefte aan te hebben. Twee mannen gaven de voorkeur deze persoonlijke zaken te bespreken met hun huisarts. Indien hetzelfde consult zou worden uitgevoerd door een (oncologie)verpleegkundige, gaf 40,5\% van 242 mannen aan dit als wenselijk te beschouwen. Ruim een kwart $(26,4 \% ; n=64)$ beschouwde een dergelijk consult enkel wenselijk indien de patiënt zelf zou aangeven hier behoefte aan te hebben en $26 \%(n=63)$ had voorkeur voor een uroloog-seksuoloog. In fig. 1 is het percentage patiënten dat zowel een consult wenst met een uroloog-seksuoloog als met een (oncologie)verpleegkundige uitgezet tegen de leeftijd in jaren waarop de diagnose werd gesteld.

Bijna de helft $(47,6 \% ; n=49)$ vond drie maanden na de behandeling het geschiktste moment voor seksuele counseling. Een derde $(33,0 \% ; n=34)$ gaf aan hier zo snel mogelijk gebruik van te willen maken, namelijk gedurende de eerste controle, ongeveer vier weken na de behandeling. Een minderheid $(11,6 \% ; n=12)$ noemde een periode van zes tot negen maanden als wenselijk en 7,8\% $(n=$ 8) had voorkeur voor seksuele counseling één jaar na de behandeling.

Wat betreft de betrokkenheid van de partners, gaf 67,9\% ( $n=144$ ) aan het belangrijk te vinden dat de partner bij de seksuele counseling wordt betrokken. Een deel (20,3\%; $n=43$ ) gaf aan dat het niet uitmaakte of de partner wel of niet aanwezig was en $11,8 \%(n=25)$ gaf de voorkeur aan intieme kwesties te bespreken zonder de aanwezigheid van de partner.

\section{Discussie}

De huidige seksuele gezondheidszorg voldoet niet aan de behoefte van mannen met ED na prostaatkankerbehandeling. Ondanks het feit dat verschillende ED-behandelmethoden beschikbaar zijn, waarvan PDE-5-remmers het meest worden voorgeschreven, is de meerderheid niet tevreden over het resultaat. Een standaard gepland consult met een uroloog-seksuoloog drie maanden na behandeling om problematiek rond seksualiteit en relatie te bespreken, wordt als meest wenselijk beschouwd. Een deel van de respondenten heeft aangegeven het tevens wenselijk te vinden indien ditzelfde consult door een (oncologie) verpleegkundige wordt uitgevoerd. De helft van de partners ervaart problemen rond seksualiteit. De meerderheid heeft echter geen behoefte aan seksuele en/of relationele hulpverlening. Desalniettemin heeft het merendeel van de mannen aangegeven de aanwezigheid van hun partner tijdens seksuele counseling als fundamenteel te beschouwen.

\section{Vergelijking met literatuur}

SD als gevolg van prostaatkankerbehandeling is een onderwerp dat niet altijd wordt besproken tijdens een followupconsult. Over het algemeen heerst een hoge tevredenheid over de ondersteunende zorg na de behandeling [4]. Lichamelijke kwesties worden echter vaker besproken dan psychosociaal gerelateerde kwesties, zoals emotionele en relationele problemen die worden veroorzaakt door SD. Gandaglia et al. onderzochten in hoeverre peniele revalidatie effectief was na een zenuwsparende RP [18]. In dit onderzoek werd peniele revalidatie omschreven als willekeurige interventie om een erectie te verkrijgen die voldoende is voor geslachtsgemeenschap en bij voorkeur de EF terug te krijgen naar de preoperatieve toestand. De langetermijneffecten voor de EF bleken inconsistent te zijn. De auteurs concludeerden dat een optimale revalidatiemethode voor mannen die waren behandeld met RP verder onderzocht moet worden. Aangaande seksualiteit na RT, werd door Incrocci vastgesteld dat ED na bestraling een multifactorieel probleem is [19]. Dit is de reden dat PDE5-remmers enkel effect hebben bij de helft van de RT-patiënten. In overeenstemming met onze studie rapporteerden patiënten die PDE-5-remmers hadden gebruikt ontevredenheid wegens het ontbreken van effectiviteit $(60 \%)$, hoge kosten $(24 \%)$ en bijwerkingen (16\%). Aangezien de helft van deze patiënten ontevreden was over hun veranderde 
seksualiteit, werd geconcludeerd dat zowel seksuele hulpverlening als meerdere behandelmethoden zouden moeten worden aangeboden [20]. Deze conclusie bevestigt de resultaten van onze studie, waarin een ruime meerderheid van de mannen aangaf behoefte te hebben aan seksuele gezondheidszorg. Aan de seksualiteit gerelateerde bijwerkingen dienen daarom niet alleen genoemd te worden op het moment dat een behandelkeuze wordt gemaakt, maar ook tijdens de follow-up dient dit onderwerp aangekaart te worden. Hierbij is het van belang dat actief gevraagd wordt naar veranderingen in seksuele gezondheid, opdat passende hulpverlening kan worden geboden. Indien advies nodig is, omdat de veranderde intimiteit leidt tot problemen binnen een relatie, is adequate verwijzing door de hulpverlener essentieel.

\section{Belang van psychoseksuele gezondheidszorg}

Psychosociale en relationele problemen die patiënten ervaren na behandeling, worden nauwelijks behandeld in vergelijking met fysieke klachten [4]. In de westerse gezondheidszorg is de focus wel meer op de kwaliteit van leven komen te liggen, omdat prostaatkankerbehandeling een grote impact heeft op de psychologische gezondheid en het welzijn van de patiënten [21]. Desalniettemin is grote vraag ontstaan naar psychoseksuele gezondheidszorg onder mannen met prostaatkanker. Een systematische review liet zien dat voldoende middelen beschikbaar zijn om adequate psychoseksuele zorg te verlenen. Het merendeel van deze middelen wordt echter nauwelijks ingezet [22].

Het is vermeldenswaardig dat de partners geen behoefte hebben aan zorgverlening rond seksualiteit en relatie. Hoewel het contrast tussen beide seksen opmerkelijk is, is dit verschil eerder beschreven door Neese et al. [11]. Zij beschrijven een groep prostaatkankerpatiënten en hun partners waarbij, net als in onze studiegroep, de patiënten meer geïnteresseerd waren in seksuele counseling dan de partners; slechts de helft had hier behoefte aan. Net als in onze studie was een deel van de partners van mening dat dergelijke obstakels te overwinnen zijn dankzij een langdurige relatie en een deel van de partners had de situatie reeds geaccepteerd. Toch ondervond een groot deel van de partners meerdere problemen door de veranderde seksualiteit en de invloed daarvan op de relatie. Toch gaven zij aan geen extra ondersteuning nodig te hebben. Wittmann et al. toonden aan dat partners van mannen die chirurgisch waren behandeld voor prostaatkanker geen seksuele activiteit ondernemen om te voorkomen dat hun partners onder druk worden gezet om op seksueel gebied te presteren [23]. Afgezien van het feit dat partners wel degelijk een onvervulde behoefte hebben aan seksuele activiteit, neigen zij andere aspecten van de relatie te belichten, opdat hun partners zich niet onzeker voelen over hun seksuele prestaties
[24]. Derhalve is het van belang deze mannen niet buiten beschouwing te laten, ondanks dat zij aangeven geen behoefte te hebben aan hulpverlening. Partners zullen de neiging hebben zichzelf weg te cijferen om onzekerheden op seksueel gebied van hun partner niet te benadrukken.

Uit de hiervoor genoemde studies kan opgemaakt worden dat de meerderheid van de mannen die zijn behandeld voor prostaatkanker niet tevreden is over de bestaande zorgverlening rond $\mathrm{SD}$. Aan seksualiteit gerelateerde bijwerkingen van een oncologische behandeling zijn doorgaans bekend bij de behandelaar. Toch blijft dit aspect vaak onbesproken [25]. Ondanks het feit dat aan de seksualiteit gerelateerde bijwerkingen wel toegelicht worden in relatie tot de behandelkeuze, kan de invloed van deze bijwerkingen door de patiënt worden onderschat. Mannen geven aan ondersteunende zorg rond de ziekte zelf bijna net zo belangrijk te vinden als ondersteunende zorg rond veranderde seksualiteit [26]. Het is dan ook van belang passende hulpverlening te bieden voor SD voor zover dit op urologisch gebied mogelijk is. Voor psychoseksuele kwesties dient gespecificeerde counseling plaats te vinden door middel van verwijzing of dienen interventies te worden ontwikkeld waarbinnen relationele problematiek de nodige aandacht krijgt.

\section{Sterke en zwakke punten}

Een sterk punt van deze studie is dat het ruime cohort op basis is van valide en betrouwbare gegevens uit een oncologische registratie van een academisch centrum. Gedurende het onderzoek waren wij in staat de lacunes tussen ondersteunende zorgverlening en hulpzoekende componenten vast te stellen in een grote groep prostaatkankerpatiënten. Zwakke punten van deze studie zijn de cross-sectionele methode waarbij interferentie kan optreden tussen gevolg en causaal verband en het retrospectieve zelfrapporterende aspect vanuit de patiënt en partner. Er zijn longitudinale studies nodig naar seksuele gezondheidszorg bij deze patiëntengroep en hun partners.

\section{Klinische implementatie}

Met dit onderzoek is geëvalueerd in hoeverre ED-behandelmethoden werden aangeboden aan patiënten binnen onze polikliniek en wat de tevredenheid hierover was. Op basis van de resultaten kan een patiëntgerichte interventie ontwikkeld en geïmplementeerd worden in de kliniek om adequate hulpverlening en ondersteunende zorg te bieden. Wij verwachten dat deze interventie niet alleen de patiënt de nodige ruimte biedt om seksuele klachten aan te kaarten, maar dat de interventie tevens zal helpen om de relatie tussen arts en patiënt te versterken die op haar beurt tot toegenomen kwaliteit van leven zal leiden [27]. Het advies is dan ook 
om drie maanden na de behandeling een standaardconsult te plannen om problemen rond veranderingen in de seksualiteit en de relatie te bespreken met zowel patiënt als partner. Indien de aangeraden zorgverlening niet kan plaatsvinden, is het van belang problemen tijdig te signaleren en over kennis te beschikken omtrent verwijsmogelijkheden naar een gespecialiseerde hulpverlener.

\section{Conclusie}

Prostaatkankerbehandeling heeft belangrijke gevolgen voor de psychoseksuele gezondheid en de relatie tussen mannen en hun partners. Desalniettemin is het een nauwelijks besproken onderwerp tijdens follow-upconsulten, wat leidt tot afname van kwaliteit van leven. PDE-5-remmers worden beschouwd als de meest gangbare behandeling voor erectiestoornissen. Deze medicatie leidt echter niet altijd tot het gewenste resultaat. De meerderheid van de mannen heeft behoefte aan ondersteunende zorg door een uroloog-seksuoloog omtrent seksuele gezondheidskwesties. Drie maanden na de behandeling wordt beschouwd als het meest wenselijke moment om veranderde seksualiteit te bespreken. Het merendeel wil dat hun partner aanwezig is tijdens seksuele counseling. Het advies is om een extra consult te plannen voor het bespreken van seksuele en relationele kwesties of om de patiënt en zijn partner door te verwijzen naar een (uroloog-)seksuoloog om deze problematiek bespreekbaar te maken.

Financiering De studie werd ondersteund door AstraZeneca en Bayer HealthCare.

Open Access This article is distributed under the terms of the Creative Commons Attribution 4.0 International License (http:// creativecommons.org/licenses/by/4.0/), which permits unrestricted use, distribution, and reproduction in any medium, provided you give appropriate credit to the original author(s) and the source, provide a link to the Creative Commons license, and indicate if changes were made.

\section{Literatuur}

1. IKNL Integraal Kankercentrum Nederland. Cijfers over incidentie prostaatkanker 2016 2016. http://www.cijfersoverkanker.nl/ selecties/incidentie_prostaat/img570360ca7c47f. Geraadpleegd op: 4 Febr 2016.

2. Potosky AL, Feuer EJ, Levin DL. Impact of screening on incidence and mortality of prostate cancer in the United States. Epidemiol Rev. 2001;23(1):181-6.

3. Chung E, Gillman M. Prostate cancer survivorship: a review of erectile dysfunction and penile rehabilitation after prostate cancer therapy. Med J Aus. 2014;200(10):582-5.

4. Watson E, Shinkins B, Frith E, et al. Symptoms, unmet needs, psychological well-being and health status in survivors of prostate cancer: implications for redesigning follow-up. BJU Int. 2015;117:E10-E19.
5. Potosky AL, Davis WW, Hoffman RM, et al. Five-year outcomes after prostatectomy or radiotherapy for prostate cancer: the prostate cancer outcomes study. J Natl Cancer Inst. 2004;96(18):1358-67.

6. Meyer JP, Gillatt DA, Lockyer R, Macdonagh R. The effect of erectile dysfunction on the quality of life of men after radical prostatectomy. BJU Int. 2003;92(9):929-31.

7. Mulhall JP, Bella AJ, Briganti A, McCullough A, Brock G. Erectile function rehabilitation in the radical prostatectomy patient. J Sex Med. 2010;7(4 Pt 2):1687-98.

8. Yiou R, Butow Z, Parisot J, et al. Is it worth continuing sexual rehabilitation after radical prostatectomy with intracavernous injection of alprostadil for more than 1 year? Sex Med. 2015;3(1):42-8.

9. Montorsi F, Brock G, Stolzenburg JU, et al. Effects of tadalafil treatment on erectile function recovery following bilateral nerve-sparing radical prostatectomy: a randomised placebo-controlled study (REACTT). Eur Urol. 2014;65(3):587-96.

10. Chambers SK, Schover L, Nielsen L, et al. Couple distress after localised prostate cancer. Support Care Cancer. 2013;21(11):2967-76.

11. Neese LE, Schover LR, Klein EA, Zippe C, Kupelian PA. Finding help for sexual problems after prostate cancer treatment: a phone survey of men's and women's perspectives. Psychooncology. 2003;12(5):463-73.

12. Beck AM, Robinson JW, Carlson LE. Sexual intimacy in heterosexual couples after prostate cancer treatment: what we know and what we still need to learn. Urol Oncol. 2009;27(2):137-43.

13. Hamilton LD, Dam D van, Wassersug RJ. The perspective of prostate cancer patients and patients' partners on the psychological burden of androgen deprivation and the dyadic adjustment of prostate cancer couples. Psychooncology. 2016;25(7):823-31.

14. Cormie P, Chambers SK, Newton RU, et al. Improving sexual health in men with prostate cancer: randomised controlled trial of exercise and psychosexual therapies. BMC Cancer. 2014;14:199.

15. Forbat L, White I, Marshall-Lucette S, Kelly D. Discussing the sexual consequences of treatment in radiotherapy and urology consultations with couples affected by prostate cancer. BJU Int. 2012;109(1):98-103.

16. Kirschner-Hermanns R, Jakse G. Quality of life following radical prostatectomy. Crit Rev Oncol Hematol. 2002;43(2):141-51.

17. Oncoline. Integraal Kankercentrum Nederland 2016. www. oncoline.nl. Geraadpleegd op: 7 Dec 2016.

18. Gandaglia G, Suardi N, Cucchiara V, et al. Penile rehabilitation after radical prostatectomy: does it work? Transl Androl Urol. 2015;4(2):110-23.

19. Incrocci L. Radiotherapy for prostate cancer and sexual health. Transl Androl Urol. 2015;4(2):124-30.

20. Incrocci L, Hop WC, Slob AK. Efficacy of sildenafil in an openlabel study as a continuation of a double-blind study in the treatment of erectile dysfunction after radiotherapy for prostate cancer. Urology. 2003;62(1):116-20.

21. Kazer MW. et al. Nursing case studies on improving health-related quality of life in older adults. Heidelberg: Springer; 2015.

22. Goonewardene SS, Persad R. Psychosexual care in prostate cancer survivorship: a systematic review. Transl Androl Urol. 2015;4(4):413-20.

23. Wittmann D, Carolan M, Given B, et al. Exploring the role of the partner in couples' sexual recovery after surgery for prostate cancer. Support Care Cancer. 2014;22(9):2509-15.

24. Boehmer U, Clark JA. Communication about prostate cancer between men and their wives. J Fam Pract. 2001;50(3):226-31.

25. Krouwel EM, Hagen JH, Nicolai MP, et al. Management of sexual side effects in the surgical oncology practice: a nationwide survey of Dutch surgical oncologists. Eur J Surg Oncol, 2015;41(9):1179-87.

26. Hyde MK, Newton RU, Galvao DA, et al. Men's help-seeking in the first year after diagnosis of localised prostate cancer. Eur J Cancer Care. 2017;26(2):e12497. doi:10.1111/ecc.12497. 
27. Ernstmann N, Weissbach L, Herden J, et al. Patient-physician-communication and health related quality of life of localized prostate cancer patients undergoing radical prostatectomy - a longitudinal multilevel analysis. BJU Int. 2016;119(3):396-405.

Lorena A. Grondhuis Palacios PhD-student

Esmée M. Krouwel aios urologie

dr. Brenda L. den Oudsten universitair hoofddocent dr. Marjolein E.M. den Ouden hoofddocent/onderzoeker dr. Gert Jan Kloens psycholoog-seksuoloog dr. Grethe van Duijn psycholoog prof. dr. Hein Putter medisch statisticus prof. dr. Rob C.M. Pelger uroloog

dr. Henk W. Elzevier uroloog-seksuoloog 